benzene rings is very restricted sterically ; thermosetting linkages may possibly involve only a few of the benzene rings, so giving a plausible explanation of the low tensile strength of phenolic resins. An entirely new conception proposed by E. G. K. Pritchett envisages a mechanically interlinked rather than a chemically cross-linked structure, the extreme rigidity rendering the substance insoluble and infusible.

\section{SALMON AND ANIMAL MIGRATION}

\author{
By Dr. A. G. HUNTSMAN \\ Fisheries Research Board of Canada and University \\ of Toronto
}

$\mathrm{M}$ ORE than two thousand years ago, Aristotle wrote that all the actions of animals are for breeding, for feeding and to avoid extremes'. Clearly such motivations of migration satisfy those who ask why animals migrate; but have they been verified and are they verifiable? Are they still accepted as explanations of migration, the only problem being to discover how the animal can accomplish wonderfu] feats? Has such an attitude been successful in elucidating migration? The statements that for birds "this question has been extolled as a mystery of mysteries"' and that for the salmon migration is accomplished by "an instinct which man cannot comprehend"3 are not reassuring.

If the matter is not yet clear, it may be because the proper approach has not been used. Perhaps migration should be considered merely as wandering, as was the original meaning. Facts against the prevalent ideas have long been known ${ }^{4}$; but no attempt seems to have been made to develop theories to include them, except as divorced from 'true migration', which has the idea of purpose either of the animal or of 'Nature'. It is not clear how we can verify the animal's purpose, and, as to Nature's purpose, it may be a mistake to assume that the animal's behaviour should be useful for survival, rather than merely not incompatible with survival of some of the race somewhere. If migration is merely wandering, that is, changing the place of abode, the problem is when and whither will an animal wander in view of its nature and of the conditions to which it is exposed. There has been a growing tendency to treat the matter thus objectively, which may permit accurate prediction.

For more than a decade, the Fisheries Research Board of Canada has been intensively studying the salmon (Salmo salar) as a somewhat representative fish. This study has provided the main facts with which we are attempting to develop a true science of fish migration.

No simple method of salmon behaviour will permit accurate prediction, since they behave most variously, as the following examples show. They may or may not spawn as parr before moving from the locality where they were spawned. On metamorphosing into smolts in the spring, they fail to spawn in that year and may or may not spewn in subsequent years up to the fifth. Usually, parr remain in streams, smolts and kelts (adults after spawning) descend, and nearspawning adults ascend; but salmon may or may not descend to or ascend from the sea as parr ${ }^{5}$, as smolts, as near-spawning adults and as kelts ${ }^{6}$. Clearly, the idea that their migrations are between breeding grounds in rivers and feeding grounds in the sea is inadequate. Some differences in behaviour have been ascribed to differences in original nature (sub-species or races); but for none of these has the original nature of the individuals been shown to be different, while correlations with environmental differences are evident and experiments fail to show that offspring of those behaving differently will behave differently under the same conditions, for example, for descent to the sea, that is, "migratory and non-migratory races" " or for time of return to streams, that is, "early and late running races".

One theory that fits the facts, but that can be only part of the complex whole, is quite simple. It is that in the rapid water of a stream the fish is carried down (as it must be more or less) in its descending, and swims actively up (as it must) in its ascending migration, these being the only directions in which stream fishes can migrate. The well-known upstream orientation of fishes, or rheotaxis, which may or may not be elicited by the flowing water, depending upon the conditions, and the more or less active swimming of the fish are all that the theory requires. Underyearling salmon have been found to vary sufficiently to separate into two groups when placed in a rather strong shallow current-those that ascend and those that descend-but they all head upstream. Similarly, when with a strong freshet in the rivers the salmon in the sea left the east coast of Sutherland near Brora for the rivers, 'droppers', that is, salmon that had ascended the rivers and remained there for some time, but had dropped down again, appeared in coastal nets ${ }^{9}$.

When entering the smolt stage for which descent is typical, salmon behave most variously. With higher, that is, swifter water, more descend ${ }^{10,8}$. Some descend quickly, some very slowly, and some fail to descend; yet they would all leave the stream in a few hours if they merely kept up from the bottom and headed downstream. Smolts marked as they left Forest Glen Brook for the large North-East Margaree River, Nova Scotia, in the spring of 1938 , arrived at a trap fifteen miles down that river in from 1 to 28 days or more. It is judged that they all could, if headed right, have descended in 12 hours. In swift water they descend tail first swimming vigorously upstream, and they sometimes ascend rapids, as may be seen when they near a trap placed in swift water. That in slow water descending fish all head downstream into a trap may mean nothing more than that all the others, if swimming faster than the water flows, are certain to be moving upstream, since the narrowness of the stream prevents movement any distance in directions other than up and down. In a lake, roaming near the surface would be apt to take them near enough to the outlet for the current to act.

In September and October of 1945, smolts were still to be found above beaver dams in Holmes Brook near Moncton, New Brunswick, in spite of freshets that were thought to have brought them down. This finds explanations in observations by Mr. C. W. Andrews in trapping smolts on the neighbouring Pollett River. With quite low water in 1944, smolts known to be in the pool above the trap failed to descend during the forty-three subsequent days of operation of the trap and no rise in water. In late evening he saw them to have descended to the brink of a shallow rapid, and they moved back up to the pool by morning. Clearly, when near the surface and down to this rapid in the 
evening, strong rheotactic reaction due to their nearness to the bottom ${ }^{11}$ caused them to swim upstream more rapidly thin the current carried them down. With deeper water, they would face less stimulus when at the surface and the current would be stronger. $\mathrm{He}$ showed experimentally in 1946 that increase in water-depth at the rapid from four to twelve inches or more resulted in descent of smolts into the trap. In work in progress, underyearling salmon in round rearing pools are seen to migrate downstream, swimming with the current, in a zone of weak current up from the bottom, when in poor condition and at unfavourably high temperature. On these and other facts is based the conclusion that salmon descend when they both wander about and fail to react strongly enough in current to remain upstream. Evidence fails of salmon at any stage heading downstream in response to strong current.

Upstream migration is more easily understood, since fishes react to current by heading upstream. Salmon may ascend from the sea a year before spawning. Even when congregated at the river mouth, they frequently fail to ascend when ascent is easy with low, slowly flowing water, but ascend quickly in spite of the greater energy required with the increasing flow of a freshet (even artificial), unless the flow is quite strong ${ }^{12}$. Also, they ascend at times at least a short distance when the river water is so warm that they are killed by heat stroke ${ }^{13}$. On these and other facts is based the conclusion that salmon ascend when they both wander about and are sufficiently stimulated to swim upstream in rapids. The stimulus may come from increase in stream flow, from wandering of the salmon into more rapid waters or in other ways.

Even a stream in heavy flood has relatively quiet water at intervals where salmon will remain if resting on the bottom. It will depend upon how they move and how the water moves as to whether or not they migrate when active. Rheotaxis is the reaction of stream fishes that permits them to continue living in streams when they move about, their swimming upstream counterbalancing the current which would otherwise carry them out. This orientation is effected through relation with the bottom, even to frequent contact ${ }^{11}$, which relation diminishes and disappears with increase in distance of the fish from the bottom.

A one-way current and a variable counter-current reaction by the fish form a proper basis for Meek's ${ }^{14}$ denatant-contranatant theory of migration. Salmon are clearly to some extent both denatant (going with the current) and contranatant (going against the current) at all stages, so that the theory is applicable to them in one-way freshwater streams of sufficient strength and shallowness, as observation readily shows. In pools with deep, very slowly moving water, evidence for it fails and other factors must operate. Meek's theory has been used to explain migration of sea fishes, but proper evidence seems to be lacking, even for its action in estuaries. The facts given us as to the movement of salmon in estuaries, even shallow ones, are that they move inwards with flood. ing tide, that is, with, not against, the current. We have failed to get evidence of contranatant migration in the sea of either herring or salmon except in restricted tidal rapids with the fish not far from the bottom.

In general, movements of the salmon in the sea seem to be in all horizontal directions and more or less to and fro, as shown by the facts of their capture and of recapture of tagged fish. Their movements are clearly determined by the conditions they meet. They become inactive with the near zero $\left({ }^{\circ} \mathrm{C}.\right)$ temperature of winter. Feeding actively as the water warms in the spring, they apparently do not roam and are not caught until they are ceasing to foed, which happens as early as May for large fish in eastern Canadian waters, but not until August for post-smolts, which corresponds with their relative fatness. They tend to hold position in rapids, which results in their collecting in channels and at river mouths. With steep salinity gradients, they tend to keep in water of low salinity, as the facts of their capture and of recapture of tagged fish show, which results in their reaching rivers. Also they tend to keep in water like that of the home stream ${ }^{15}$, which is apt to take them sooner or later to the home stream, if far from it.

With such behaviour, they collect in the river outflow as the season progresses, but do not necessarily ascend. Some stimulus seems to be required for them to do more than swim sufficiently to hold position at the river mouth. A freshet may start their ascent, which is directed by rheotaxis. Underyearling salmon in a trough ascend quickly when stimulated by a local rapid increase in flow from lowering of the surface level downstream, although ascent then requires more effort. Adult salmon, when stimulated by the increased flow of a freshet, will for the most part not ascend when the current is strongest at the height of the freshet, but only as the current weakens. When sharp, stimulating, artificial freshets were made in the Moser River, Nova Scotia, in the dry season of 1942, more than twice as many salmon entered as were to be expected from counts of smolts and adults for the preceding three years ${ }^{11}$, with the water generally so low that the fish could be readily caught in the evening on the rapids by poachers who made rough traps or mazes of stones for the purpose. With such freshets in the somewhat wet season of 1943 and with the native grilse having been marked the previous year as smolts, from one quarter to more than one half of the entering grilse were unmarked and presumably foreign fish ${ }^{16}$, the proportion rising with advance in the season and particularly with heavy floods that doubtless brought in fish that were farther out to sea. Even through the spawning period, with continued absence of freshets from summer to the December freeze-up in 1946, salmon did not appear in traps operated on Holmes Brook, North River and Bennett Brook above the main Petitcodiac River, as they had done in previous years in going to spawning grounds, even though some were in the main river from mid. summer ${ }^{17}$. If salmon must be stimulated to go upstream to spawn, should they be used as the chief example among fishes for true migration, defined ${ }^{18}$ as "a racial custom, enregistered in the animal's constitution"?

With pressure of a dense population, planted salmon spread more widely, as planting experiments have shown. The facts indicate that the brook trout (Salvelinus fontinalis) shows this factor by failing to migrate down to the sea when heavy fishing lessens population pressure. Thэ room required to stop migration changes with increase in size of fish, so that large fish are generally found in lower, larger waters. Planting of tagged kelts above Shubenacadio Lake has just shown extent of descent to large lakes or the sea to be correlated with the size of the fish.

I am deeply grateful to many colleagues who, with other ideas, have kindly responded to appeals for 
criticism, greatly aiding this presentation of the matter.

1 "Aristotelis Opera", IV (Hist. An.), 276 (Ed. Bekker, Oxford, 1837). "Gadow, H., "Encycl. Brit.", ed. XI, 18, 433 (1911).

"Calderwood, W. L., "A Survey of Salmon Fisheries in Eastern Canada"' (New Y̧ork, July 1930).

- Huntsman, A. G., Nature, 141, 421 (1938).

'Huntsman, A. G., J. Fish. Res. Bd. Can., 6, 399 (1945).

- Huntsman, A. G., J. Fish. Res. Bd. Can., 4, 96 (1938).

${ }^{7}$ Huntsman, A. G., Science, 105, 289 (1947).

- White, H. C., and Huntsman, A. G., J. Biol. Bd. Can., 4, 1 (1938).

- Menzies, W. J. M., Fish. Scotl., Salm. Fish., 1915, II, 4 (1916).

${ }^{10}$ Berry, J., Fish. Scotl., Salm. Fish., 1931, VI, 10 (1932).

11 Dykgraaf, S., Z. Phys., 20, 212 (1933).

12 Huntsman, A. G., Ann. Rep. Fish. Res. Bd. Can., 1942, 29 (1943).

${ }^{13}$ Huntsman, A. G., J. Fish. Res. Bd. Can, , 5, 485 (1942).

"Meek, A., "The Migrations of Fish", 19 (London, 1916).

${ }^{18}$ Huntsman, A. G., Ann. Rep. Fish. Res. Bd. Can., 1944, 28 (1945).

10 Huntsman, A. G., Ann. Rep. Fish. Res. Bd. Can., 1943, 35 (1944).

${ }^{17}$ Huntsman, A. G., Ann. Rep. Fish. Res. Bd. Can., 1946, 31 (1947).

18 Thomson, J. A., "Encycl. Brit.", 15, 473 (1942).

\section{SUBMICROSCOPIC STRUCTURE OF THE BACTERIAL CELL, AS SHOWN BY THE ELECTRON MICROSCOPE*}

\author{
BY DR. STUART MUDD
}

School of Medicine, University of Pennsylvania

$\mathrm{T}$ HE wall of the bacterial cell is solid. The cellwall may maintain its approximate shape after cytolysis; on breaking it may present a jagged line of fracture ${ }^{1}$. Within the cell-wall, and normally doubtless closely applied to it, is the cytoplasmic membrane enveloping a fluid or potentially fluid protoplasm. In electron micrographs the protoplasm often is appreciably separated from the cell-wall ${ }^{2}$. This is doubtless a shrinkage artefact due to desiccation in the electron microscope, which operates in a high vacuum. The protoplast and in particular the cytoplasmic membrane are stained and visible, the cell-wall unstained and not seen, in routine bacteriological preparations. Flagella, if present, arise from the protoplast and pass through the cellwall, at least in vibrios. They are of uniform diameter somewhat characteristic of the bacterial species. They are not artefacts or mucous threads ${ }^{3}$. Capsules, as in the case of the pneumococcus, are extracellular gels surrounding the cell-wall ${ }^{4}$.

Combination of bacterial antigens with antibodies may be directly observed with the electron microscope. Specific antibcdies combine with somatic and flagellar antigens of non-capsulated bacteria to form surface deposits, respectively, on the cell-wall and flagella ${ }^{5}$. Non-specific components of serum (complement) may be adsorbed secondarily on the antigen-antibody complex ${ }^{2}$. Antiserum permeates the capsular gel of the pneumococcus; antibody combines with homologous capsular antigen and nonspecific serum components are adsorbed; the swollen gel resulting is opaque to electrons ${ }^{6}$.

Study of the internal structure of the bacterial protoplast has been retarded by the 'opacity' to electrons (diffuse scattering of electrons) of the protoplast, in particular of Gram-positive species, and by insufficient contrast of structures within the protoplast. In the special case of the sporulation and spore germination of an aerobic bacillus (Bacillus mycoides), Knaysi, Baker and Hillier ${ }^{7}$ have revealed much additional detail by the use of a research

* From a Symposium on Electron Microscopy at the Nobel Institute of Physies, Stockholm, Sweden, July 16, 1947, in connexion with the Sixth International Congress for Experimental Cytology. model electron microscope operating at higher than ordinary voltage (150 kv.).

Knaysi and Baker ${ }^{8}$ have also discovered an elegant method of making internal structure more apparent. Bacillus mycoides is grown in a nitrogen-free glucosecontaining medium, buffered with sodium acetate. Under these conditions the electron-scattering ribonucleic acid of the cytoplasmic membrane and protoplast is reduced to a minimum, and two types of internal structures are revealed. The first are opaque bodies 0.22 by $0.29 \mu$ to 0.43 by $0.50 \mu$ in diameter; one to six of these are found in each cell; these bodies are present in all stages of development; they divide; they are included in the forespore when sporulation occurs; they take nuclear stains. They are interpreted as nuclei.

The second type of bodies are thin, each with circular or elliptical outline; they are 0.08 to $0.17 \mu$ in diameter; a few to about forty are present per cell. "They are part of the cytoplasmic membrane and, except when they appear homogeneous, they cannot be structurally differentiated from the rest of that membrane. Both seem to consist chiefly of a net-work of beaded threads and granules, probably representing complex molecules." Electron micrographs of Bacteroides funduliformis by W. E. Smith, Mudd and Hillier also show a finely reticulated structure of the bacterial protoplasm ${ }^{9}$.

The structure thus far made manifest in the bacterial cell, even with the aid of the electron microscope, is much simpler than the remarkable synthetic capacities of bacteria would seem to require. Cells of many kinds of bacteria, furnished only with water, salts, glucose and simple sources of carbon and nitrogen, can synthesize proteins, complex carbohydrates, lipids, ribose and desoxyribose nucleic acids, growth accessories and enzymes, all organised into characteristic and reproducible protoplasmic systems. The cell can reproduce itself and divide within half an hour at body temperature. These feats of chemical synthesis and organisation, which cannot be duplicated by the finest chemical laboratories in existence, are accomplished within a cell a few microns in length and less than a micron in diameter. The plain facts would seem fantastic if they were not so familiar.

W. Seifriz, K. H. Meyer and others ${ }^{10}$ have pointed out that the elastic and thixotropic properties of protoplasm imply a three-dimensional lattice of elastic and solvated protein molecules or micelles. The width and thickness of extended molecules of ordinary proteins (about $10 \mathrm{~A}$. by $4.5 \mathrm{~A}$.) are at, or just beyond, the present limit of resolution of the electron microscope, when full resolution is taken advantage of by use of the techniques of shadowcasting ${ }^{11}$, or of surface replica ${ }^{12}$. Globular protein molecules ${ }^{13}$ and fibres composed of a small number of aggregated, extended protein molecules are detectable under favourable conditions with the electron microscope. The electron micrographs of bacteria cited above and those of Porter, Claude and Fullam $^{14}$ of the hyaloplasm of fibroblasts are compatible with the reticular protein framework which has been postulated as necessary to explain the physical properties of protoplasm.

It may be useful to proceed in imagination beyond the present visual evidence of fine structure. The interstices of the reticulum may be supposed to be filled with an aqueous phase. The simultaneous occurrence of complex reactions, involving energy utilization, synthesis, and organisation of the 